\title{
JUURNAL.RU
}

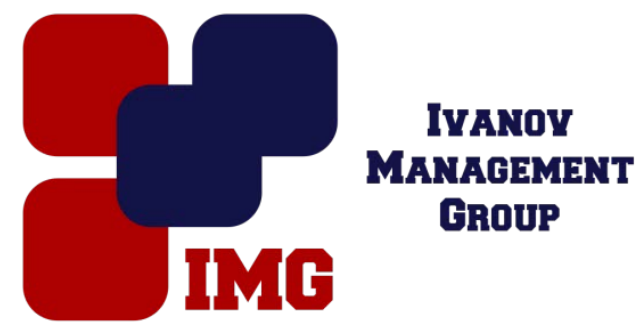

Ключников С.О.

ФКОУ ВПО “Академия права и управления Федеральной службы исполнения наказаний” Институт подготовки государственных и муниципальных служащих Рязань, Россия

doi: 10.18411/lj-30-04-2017-3-13

idsp 000001:lj-30-04-2017-3-13

\section{Соотношение справедливости и равенства всех перед правом}

\section{Аннотация}

В данной научной статье рассматриваются проблемы справедливости и равенства всех перед правом, а также их взаимосвязь, в различных исторических периодах.

Ключевые слова: равенство, свобода, справедливость, право, формальное равенство.

Постановка проблемы. Философско-правовая теория юридического позитивизма исходит из того, что право не определяется через равенство или справедливость, но не обусловливается ими, а опирается на определенный нормативно определенный порядок, который является выше идеал справедливости. Исходя из того, что понимание равенства или справедливости и других нравственных ценностей являются относительными, все же нужно констатировать, что реалии, а также последние научные исследования убедительно доказывают факт очень тесного взаимодействия и взаимообусловленности равенства, справедливости и права. Именно эти положения составляют актуальность затронутой проблематики.

Анализ исследований и публикаций. Проблема равенства и неравенства разрабатывалась, начиная уже со времен античности. Выдающиеся философы античного мира, такие как Платон, Аристотель, Сенека, Аврелий, Дионисий Ареопагит, рассматривали онтологию и аксиологии общественного неравенства. 
В более поздние исторические периоды неравенство активно изучалась в ее различных структурных и содержательных аспектах.

В частности, в $\mathrm{XX}$ в. культурный и интеллектуальный аспекты неравенства были подвергнуты всестороннему анализу вработах П. Бурдье, Р. Беккра, М. Кроуфорда, Л. Эдвинссона, Дж. Ролза и ряда других исследователей.

В советский период проблема неравенства в основном исследовалась в контексте проблематики ее преодоления, исходя из доминирующего в то время идеала полной социального равенства. Однако работы ученых того периода внесли много существенного в понимание проблемы неравенства. Стоит отметить таких исследователей, как Г. Ашин, В. Давидович, Ю. Давыдов, В. Радаев, Р. Рывкина, чьи работы содержат весьма ценные материалы и результаты.

В период постсоветской истории исследования проблем неравенства, когда цензурно-идеологические ограничения были сняты, идеи этих исследователей получили всестороннее развитие и продолжение. Отмечая работы, посвященные исследованию проблем неравенства, можно выделить труды Д. Константиновского, Т. Заславской, М. Радовель, Е. Ярской-Смирновой, И. Мостовой, В. Ильина.

Постановка задачи. Целью научной статьи является определение взаимосвязи морально-правовых категорий «равенство» и «справедливость»с определяющими теоретико-правовыми основами формирования и развития национального права на современном этапе государства.

Изложение основного материала исследования. Формальное равенство является необходимым способом социального бытия свободы, поскольку любой другой эффективной формы бытия и выражения свободы в социальном взаимодействии людей, кроме правовой, человечество до сих пор не выработало. Это связано, в частности, тем, что, будучи введенной в единую всеобщую меру, которая определяется взаимным и одинаковым ограничением свободы всех участников социальной коммуникации.

Таким образом, формальное равенство - это базовый и универсальный принцип правового регулирования, который комплексно определяет содержание правопорядка, поскольку воплощает в себе требования, как к содержанию позитивного права, так и к формам и способам его установки и защиты. Кроме этого, принцип формального равенства может быть конкретизирован в той или иной жизненной ситуации в непротиворечивую систему формально определенных правил поведения, то есть правовых норм (позитивного права). 
Вместе с тем, формальное равенство является формулой, выражающей справедливость права итого порядка, который оно устанавливает. При этом такое толкование справедливости лишено элементов произвольности, поскольку оно предполагает упорядочение общественных отношений на основе признания за каждым человеком формально равной возможности реализации свободы, как своей сущностной характеристики, определяющей природу человека и, в равной степени, принадлежит всем людям. Отрицание же правового характера и значения справедливости приводит к тому, что она начинает пониматься как любое не правовое начало, то есть требование «уравниловки» или привилегий, те или иные личные экономические, политические, национальные, социальные, эстетические и другие интересы или требования. Тем самым правовое значение справедливости подменяется индивидуальным, групповым или классовым интересом и, в связи с этим, произвольным содержанием и партикулярными требованиями.

Итак, взаимопомощь, справедливость, мораль - это те последовательные этапы, которые мы наблюдаем, изучая мир человека. Право как форма бытия и выражение свободы является формой бытия равной степени, одинакового масштаба свободы для всех субъектов соответствующих правоотношений. Правовое равенство - это равенство свободных и независимых субъектов права, потенциальные возможности которых определены единственной мерой, единственным критерием. Таким критерием, основой правового уравнивания фактически различных людей является их свобода. Право поэтому и ценное для членов общества, оно требует фактического единообразия индивидов.

Каждый из них остается уникально-неповторимым. Право уравнивает людей в свободе, которая им необходима для самореализации, самовыражения, осознания своей неповторимости.

Bсе попытки формализовать понятие справедливости той или иной степени происходят из концепции Аристотеля, которая предусматривает формулу уравнения «предоставление» и «получение» в процессе социального обмена (так называемая уравнительная справедливость) и распределение благ пропорционально вкладу каждого в общее дело (так называемая распределительная справедливость).

Суть этих требований выражается в двух широко и взаимосвязанных между собой постулатах: «Каждому свое» и «Ровно за равное». В этом случае речь идет о выявление характеристик правопорядка, обеспечивающих его 
общую приемлемость, равную для всех «выгодность», а потому и легитимизации его общеобязательности и принудительности.

Философ древнего мира Аристотель, видя связь равенства и справедливости, отметил, что понятие «справедливость» - это одновременно проявление как законного, так и равномерного, а «несправедливость» противозаконное и неправомерное(Отношение к людям).

Цицерон отмечал: «Под действие закона должны подпадать все». Надо, считал мыслитель, установить «не только для магистров мере их власти, но и для граждан меру их подчиненности ». Ведь и «тот, кто, разумно управляет, рано или поздно будет подчиняться, а тот, кто покорно подчиняется, стоит того, чтобы рано или поздно начать управлять». мыслях раз и заложена идея правового равенства - принципу унификации граждан по единому критерию, единственным масштабом свободы, имеет отразиться в законе(Позитивном праве).

Право - это формально-содержательное равенство. Подменная, путаница понятий«Фактический» и «формальная» равенство является довольно распространенным явлением в науке (например, в недавнем социалистическом прошлом формальное равенство как принцип общественной жизни было подменено фактической равенством, то есть уравниловкой). В праве свобода человека нормирована и его развитие свидетельствует, что право, воплощенное в принципе формального равенства, является эффективным регулятором общественной жизни по сравнению с другими социальными регуляторами (моралью, религиозными нормами, корпоративным правом, обычаями и т.д.).

Принцип формального равенства предусматривает, что фактически осуществленные субъектами реальные субъективные права будут неравны. Формальное право - это лишь абстрактная возможность, способна приобрести в соответствии с одинакового масштаба, общих принципов, равной степени свое право на то: право на образование, жилье, достойную оплату труда, качественное медицинское обслуживание, утверждения гендерного равенства и тому подобное. Ученые-правоведы утверждают, что везде, где действует принцип формального равенства, является правовое начало. Где нет принципа равенства, там и права как такового тоже не существует.

Римский юрист Ульпиан считал, что тому, кто занимается правом, нужно сначала исследовать, откуда происходит название права. Правовое равенство (соответствие,равномерность)собственноивыражаетсодержаниесправедливостип рава. 
Римские юристы пользовались понятиями «aeguumjus» (эквивалентно, равное право) и «јusaniguum» (право неэквивалентное, неровное). Правовой эквивалент означал в них равную справедливость или справедливую равенство, является одной сущностью. Ульпиан отмечал, что справедливость есть неизменной и устоявшейся волей предоставлять каждому его право. Предписания права

просты: житьчестно,НЕоказыватьущербадругом,каждомуотдаватьто,чтоемупринадлежит

Справедливость есть познанием божественных и человеческих дел, наука о справедливом и несправедливом.

Правовая справедливость - это справедливость, которая принадлежит всем, то есть должна быть признана всеми, всем обществом, прежде всего вследствие восприятия канонов и принципов справедливости, а следовательно, позитивного права в целом. Оно призвано упорядочивать общественную жизнь, a не провоцировать хаос - приводить к тому, когда в действие вступают несанкционированные регуляторы общественных отношений (например, нормы, регламентирующие проведения соглашений в теневой экономике).

Подмена положительного правового начала не правовыми регуляторами приведет к разрушению права, уничтожает и само общество. В основу правовой справедливости положена справедливость моральная. Если правовая справедливость опирается на другие принципы, тогда позитивное право уничтожается вообще.

Исследуя выходные телеологические культурные ценности, которые воплощаются в праве и обеспечиваются с помощью его формально определенных норм, определенное внимание, по нашему мнению, следует уделить также и гуманизма, содержание которого неразрывно связано со свободой, справедливостью и равенством. Эта взаимосвязь проявляется, прежде всего, в том, что гуманизм предполагает признание человека как личности, его прав на свободное развитие, утверждение блага человека как критерия оценки общественных отношений и тому подобное.

Выводы. Итак, современное национальное законодательство должно быть образцом свободы, равенства, сосредоточением справедливости, гарантом права на самореализацию, защиты человека от произвола государства. И, в конце концов, быть доступным и понятным и восприниматься не только профессионалами, но и прежде всего рядовыми гражданами нашего государства. 
1. Аристотель. Сочинения: в 4-х т. Т. 4 (Аристотель) / пер. с древнегреч.; общ.ред. А. И. Доватура. - М.: Мысль, 1983. - 830 с.

2. Варламова Н. В. Понимание свободы, равенства и справедливости в контексте либертатной концепции права / Н. В. Варламова // Российский ежегодник теории права / под ред. д-ра юрид. наук А. В. Полякова. - СПб.: ООО «Университетский издательский консорциум «Юридическая книга», 2009. - С. 43-66.

3. Варламова Н. Право и справедливость: соотношение в контексте различных типов правопонимания / Н. Варламова // Право - 2010. - № 4. - С. 70-75.

4. История политических и правовых учений: учеб. для вузов / [авт. кол.: В. Г. Графский, Н.М. Золотухина, Л.С. Мамут и др.]; под общ.ред. члена-кор. РАН В. С. Нерсесянца. - М.: ИНФРА-М, 1996. - 736 с.

5. Нерсесянц В. С. Философия права : учеб.для вузов / В. С. Нерсесянц. - [2-е изд., перераб. и доп.] - М.: Норма, 2006. - 848 с.

6. Нерсесянц В. С. Юриспруденция. Введение в курс общей теории права и государства [для юридических вузов и факультетов] / В. С. Нерсесянц. - М.: НОРМА, ИНФРА-М, 1998. $288 \mathrm{c}$.

7. Фуллер Л. Л. Позитивизм и верность праву. Ответ профессору Харту / Л. Л. Фуллер // Правоведение. - 2005. - № 6. - СПб.: Изд-во Санкт-Петербург.ун-та. - С. 124-159.

8. Ц Цицерон. Диалоги: О государстве. О законах / Цицерон / пер. В. О. Горенштейна; прим. И. Н. Веселовского и В. О. Горенштейна; отв. ред. С. Л. Утченко. - М.: Наука, 1966. - 224 c. 